\title{
Corporate governance evaluation of Chinese listed companies
}

\author{
Weian Li \\ Tianjin Univeisity of Finance and Economic, Tianjin, China
}

\begin{abstract}
Purpose - In recent years, the quality and environment of global corporate governance have drawn attention from researchers and practitioners. Based on the public information of Chinese listed companies (CLCs), the Evaluation Research Group of China Academy of Corporate Governance at Nankai University developed the first corporate governance index system that includes six dimensions to evaluate the status of the governance of CLCs.
\end{abstract}

Design/methodology/approach - This paper reports the findings of the annual evaluation in 2017.

Findings - The authors found that five of the six dimensions of CLC governance index increased, except for shareholder governance index. Management-level governance and information disclosure index increased most significantly.

Originality/value - Through the evaluation, the authors discovered some governance problems of CLCs and proposed some corresponding suggestions to improve the effectiveness of corporate governance of these companies.

Keywords Corporate governance evaluation, Corporate governance index, Chinese listed companies

Paper type Editorial

\section{Introduction}

In recent years, the focus of corporate governance research has expanded from major developed countries such as America, Britain, Japan and Germany to emerging market countries. The quality and environment of corporate governance are of great interest to researchers. During this transitional process, corporate governance evaluation is a key link. Through evaluation, researchers can discover problems of corporate governance to improve the effectiveness of corporate governance. Since the reform of the Chinese economic system in 1978, corporate governance has also transited from an administration-oriented governance model to an economy-oriented governance model, following the principles of Chinese corporate governance reform. Chinese corporate governance has also experienced a significant transformation process from "similarity in form" to "similarity in spirit". Looking back on the development of the Chinese economy and corporations over the last four decades, we see the corporate governance practice in terms of four phases, which are concept introduction, structural reform, mechanism building, and effectiveness improvement. At present, China is in the fourth phase.

Based on the public information of Chinese listed companies (CLC), the Evaluation Research Group (ERG) of China Academy of Corporate Governance (CACG) at Nankai University developed the first corporate governance index (CGI) system. The system

The current research was supported by National Natural Science Fund Projects, National Social Sciences Fund Projects, Ministry of Education Program of Chang Jiang Distinguished Professors, Ministry of Education Project of Key Research Institute of Humanities and Social Sciences in Universities, Higher Outstanding Young Teachers Teaching and Research Projects Incentive Fund, 211 Project and 985 Project of Nankai University.

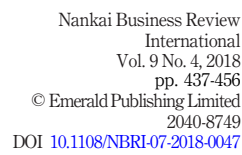


NBRI

9,4

includes six dimensions, which are shareholder governance, board of directors governance, board of supervisors governance, management-level governance, information disclosure and stakeholder governance. There are 19 secondary dimensions and over 80 evaluation indicators. The system aims to make a systematic evaluation of the corporate governance status of CLC. Moreover, CLC CGI (CCGI $\left.{ }^{\mathrm{NK}}\right)$, known as the predictor of CLC, is annually reported in this system. Since 2004, when the index of CLC was published, ERG has conducted annual evaluations based on a sample of CLC companies. This paper reports the evaluation results in 2017.

The structure of this paper is as follows. Section 2 reviews the development of $\mathrm{CCGI}^{\mathrm{NK}}$. Section 3 mainly describes the composition of CCGI ${ }^{\mathrm{NK}}$. Section 4 reports the overall analysis of the corporate governance of CLC in 2017. Finally, we draw conclusions and propose some research directions of corporate governance in Section 5 .

\section{Corporate governance evaluation and governance index}

\subsection{Significance of corporate governance evaluation}

2.1.1 Corporate governance and healthy development of the stock market. A healthy stock market requires four conditions, which are fair fundamentals in the macro economy, highquality listed companies, mature and rational investors and moderate and effective regulations (Cheng, 2015). Corporate governance evaluation stems from investors' attention to company values because investors examine not only a company's performance appraisal but also corporate governance conditions, considering corporate governance as one of the most important decision-making factors. Corporate governance is the most important aspect of a company's quality. A complete corporate governance mechanism is crucial to ensure market order, and corporate governance reform has become a global focus.

The scope of the academic research has accordingly expanded from theories about corporate governance structure and mechanisms to practical guidance on corporate governance models and principles. Currently, corporate governance quality and environment have attracted much attention and the research focus has shifted towards corporate governance evaluation and the development of CGI. Through three decades of exploration and accumulation, Chinese corporate governance has yielded significant achievement. Related laws, regulations and policy systems have been developed so that corporate governance can comply with. A multi-level regulatory system has also been built, which can constrain corporate governance. In addition, the corporate governance level of listed companies has gradually improved.

Although the corporate governance of CLC is younger than that of foreign enterprises, it has been through two steps in building a corporate governance structure and corporate governance mechanism. At present, the corporate governance of CLC has entered an important phase of quality-centric reform and development. Building structures and mechanisms alone is not enough and what matters is to achieve the effectiveness of corporate governance.

2.1.2 Further elaborations. One of the important tasks of corporate governance research is to explore how to build a complete and scientific corporate governance evaluation system. Through running this system, researchers can provide helpful information for investors to make decisions. On the other hand, such a system can benefit companies directly. It provides a succinct analysis of a company's corporate governance (structure and mechanism), helps identify and analyze problems in the rights and interests protection of stakeholders, and improves corporate governance quality and company values. The theoretical and practical focuses of corporate governance are in urgent need for understanding the following questions: What is the corporate governance quality of Chinese companies? How can the 
shareholders' meeting be regulated to ensure the independence of a company? How should the board of directors run a complete decision-making and monitoring regime? What incentive and constraint mechanisms should be taken to effectively reduce agency costs and push agents to work hard for a company's long-term development? What are the major factors determining corporate governance quality? What are the risks of corporate governance and what are the extents of these risks? How would the building and improvement of a corporate governance mechanism impact company performance?

The core to answer the above questions is to build a corporate governance evaluation system and evaluation index that adapts to the Chinese corporate governance environment. Such a system would allow us to understand corporate governance structure and its mechanisms. It would also help identify the status, sources, extents and controls of corporate governance risks in Chinese companies. Further, the system would observe and analyze the status quo among companies, including the existing risks and governance performance of Chinese companies in controlling shareholders' behaviors, the operations of the board of directors, the incentives and constraints on the management level, the monitoring of the board of supervisors and information disclosure practices. The importance of a systematic understanding of corporate governance can be expressed in the following points.

First, it is conducive to the government's monitoring and promoting capital market improvement and development. A CGI reflects corporate governance level. A detailed compilation and regular issues of CGI enable regulatory authorities to timely control corporate governance structure and mechanism status of their regulatory subjects. These authorities can direct their regulatory powers to the right targets and use the index as a form of feedback. Additionally, the index helps security regulators to efficiently assess the status of corporate governance of CLS and the implementation of related regulations and systems. By taking advantage of this system, security regulators can, in a timely manner, understand the extent to which their regulatory subjects are improving in terms of controlling shareholders' behaviors, selecting a board of directors, board of supervisors and senior managers, incentivizing and constraining their organization's members, disclosing information, implementing internal controls and managing corporate governance risks. Timely information on these activities is essential for regulatory authorities to play their roles effectively.

Second, it helps build reputations for companies and promote the quality of the security market. Paying attention to financing and sustainable development, a company must emphasize its image in the eyes of the security market and investors. The development of a corporate governance evaluation system can track the status of corporate governance in a complete, systematic and timely manner, thus forming a powerful reputation measurement. Regularly issuing evaluation results complements the weak constraint of the external environment for Chinese enterprises. A reputation constraint, by way of regularly issuing corporate governance status reports, will motivate companies to continuously improve their governance and reduce related risk to the minimum. This will ultimately increase the quality of the security market and intensify credit reputations. A company's credit is built upon a fair corporate governance structure and supporting mechanisms. A company with a fair corporate governance status certainly has fair enterprise credit. A dynamic comparison of CGI across different periods can reflect the changing conditions of corporate governance quality of a company. Thus, it is beneficial to develop a dynamic reputation measurement and constraint.

Third, for the purpose of monitoring a company, the index is conducive to improvement and scientific decision-makings. CGI enables companies (the subjects being evaluated) to control the overall elements of their corporate governance, i.e. information disclosure, 
NBRI

9,4

internal controls, timely diagnose of possible problems and targeted measures for improvement. CGI also handles the stakeholders involved, such as controlling shareholders, the board of directors, the board of supervisors and managers, to ensure that the corporate governance structure and mechanisms are in fair status. Such a selfanalysis can improve not only corporate leadership but also the company's competitiveness. Regular corporate governance evaluation information will enable the administrative authorities to manage the potential risks of companies and adopt active measures to reduce and avoid regulatory risks. By taking advantage of the full information of corporate governance quality and risks provided by the evaluation report, a company can understand its investment targets and apply information to its scientific decision-makings. For example, the application of the corporate governance scoring card helps guide the scientific decision-makings of a company.

Fourth, CGI provides an identification tool and guides the investment for investors. Quantifying corporate governance in an index enables investors to compare corporate governance levels and the risks of different companies. According to CGI, investors can receive early warnings of risks, and the information on corporate governance cost and performance. This informational advantage helps judge the corporate governance status, risk trend and potential investment value of a given company, thus improving their decision-makings. The traditional investor analysis that uses financial indicators has limitations. The index further promotes information disclosure, decreases information asymmetry, and improves objective decision-makings. Such an index is not without precedent. For example, the investment selection principle of the LENS Investment Management Company, established in 1992, is to find companies whose values are underestimated and can be improved through corporate governance (from the perspectives of financial evaluation and corporate governance). Also, America's Institutional Shareholder Services (ISS) built a corporate governance stock price index with FTSE, establishing corporate governance consulting services for its members. South Korea also built a corporate governance stock price index.

Fifth, an evaluation system and index is conducive to building an empirical research platform on corporate governance. Chinese CGI expands corporate governance research from a theoretical focus to a quantitative and applied focus. The latter facilitates solving scientific problems of corporate governance quality, corporate governance risk, corporate governance cost and corporate governance performance measurements. A series of survey research during the process of corporate governance evaluation are important data resources, particularly as CGI is comparable across firms. This research platform combines corporate governance research with practical and current data.

\subsection{Major corporate governance evaluation systems}

2.2.1 Corporate governance evaluation systems. Corporate governance evaluation and indexes provide guidance for basic theoretical and applied research, studies of corporate governance and principles, as well as corporate governance for commercial and noncommercial firms. Attention to corporate governance evaluation by scholars is based on meeting the requirements of corporate governance for practical development, especially in meeting the requirements of institutional investors.

Corporate governance evaluation started from the performance analysis of board of directors proposed by Jackson Martindell in 1950. Shortly after that, commercial organizations introduced several evaluation systems. The earliest standardized corporate governance evaluation research was a program to evaluate boards of directors, designed by the America's Institutional Investor Association in 1952. A series of research results 
regarding corporate governance diagnosis and evaluation appeared afterwards, such as the 22-question diagnosing boards of directors developed by Salmon (1993). Standard and Poor's (S\&P) operated a corporate governance service system starting from 1998 (revised in 2004). In 1999, Deminor launched the Deminor corporate governance evaluation system. In 2000, Credit Lyonnais Securities Asia (CLSA) introduced the CLSA corporate governance evaluation system. In 2003, CACG at Nankai University initiated China's first complete and systematic corporate governance evaluation system, published the Chinese Corporate Governance Evaluation Report in 2004, and released Chinese CGI of Listed Companies companies $\left(\mathrm{CCGI}^{\mathrm{NK}}\right)$. America's ISS also built a global corporate governance status database to provide corporate governance services for its members. In addition, Brunswick Warburg, ICLCG (Institute of Corporate Law and Corporate Governance), ICRA (Information and Credit Rating Agency [ICRA]), the World Bank, Thailand, South Korea, Japan (CGS, JCG Index) and Taiwan implemented their own corporate governance and grading systems. Please refer to Table I for detailed information.

2.2.2 Evaluation of corporate governance evaluation systems. Generally speaking, corporate governance evaluation systems have four common features as follows. First, evaluation systems are composed of a series of detailed indicators and each evaluation system contains three factors, which are shareholders' rights, structure of board of directors, and information disclosure. Second, among all evaluation systems, the scoring characteristics are the same. Lower score means poorer corporate governance level, and vice versa. However, there are two exceptions. One is the ICRA evaluation system, which utilizes the opposite scoring method, with Corporate Governance Ranking 1 (CGR1) representing the best corporate governance status and CGR6 the worst. The other exception is the governance risk analysis of Brunswick Warburg, which calculates in the form of punishment scores (a higher score means bigger governance risk). Third, most of the evaluation systems use weighted rankings, giving different weights according to a factor's degree of importance and then calculating a corporate governance evaluation score. Fourth, methods to acquire information needed by evaluations are the same, which mainly come from public and available information through interviews with key employees of companies.

Major differences of these evaluation systems lie in two aspects. First, some evaluation systems are used to evaluate a certain country's corporate governance status (such as Brunswick Warburg's) while others involve several countries' corporate governance evaluations (such as S\&P, CLSA and Deminor) which contain analyses at the country's level and use similar criteria. Second, the focus, criteria, and evaluation indicators' composition are different. For example, S\&P formulates its evaluation indicator system based on corporate governance principles put forward by OECD and CalPERS. Evaluations at the company level include four dimensions of ownership structure and its impact, i.e. stakeholder's relationships, financial transparency, information disclosure, and the structure and operations of the board of directors. CLSA's evaluation system involves eight dimensions of constraints on management levels, transparency, protection of small shareholders, independence, fairness, accountability, shareholders' cash returns and corporate social responsibility.

The research and applications of corporate governance evaluations have effectively guided corporate governance practices. As we can see from the comparison of different evaluation systems listed above, different evaluation systems have different applicable conditions. Notably, Chinese companies' governance environment, structure and mechanisms are greatly different from those of foreign companies. Therefore, directly applying foreign evaluation systems to China is not appropriate. Only by learning from international experiences and combining details of the legal environment, political system, 
NBRI

9,4

442
Institutions or Individuals

Jackson Martindell

Standard and Poor (S\&P)

Deminor

CLSA

ISS

DVFA

Brunswick Warburg

Institutions of corporate law and corporate governance (ICLCG)

ICRA

Japan's CGS of Hideaki Miyajim, Kenji Haramura, Inagaki Kenichi, etc.

JCGIndex

Thailand

South Korea

The City University of HK

Fu Jen Catholic University

GMI

(governance metrics international

The World Bank

Table I.

Major corporate governance evaluation systems $\mathrm{CCGI}^{\mathrm{NK}}$
Evaluation contents

Social contributions, services to shareholders, performance analysis of board of directors, company's financial policies

Ownership structure, rights and interrelations of stakeholders, financial transparency and information disclosure, structures and procedures of board of directors Shareholders' rights and obligations, scope of takeover defense, information disclosure transparency, structures of board of directors

Constraints on management levels, transparency, protections for small shareholders, independence, fairness, accountability, shareholders' cash returns, corporate social responsibility

Structure and composition of board of directors and its major committees, articles of association and regulations, laws of the state where the company is located, compensation of management levels and members of board of directors, related financial performance, "advancing" corporate governance practices, shareholding proportion of senior managers, education received by board directors

Shareholders' rights, governance committee, transparency, company management and audit

Transparency, equity dispersion extent, transferred assets/price, merger/ restructuring, bankruptcy, ownership and bidding limit, management attitude to outsiders, registration type

Information disclosure, ownership structure, structure of board of directors and of management levels, shareholders' rights, expropriation risks and corporate governance history of the company

Ownership structure, structure of management levels (including structures of each board director committee), quality of financial reports and other disclosures, extent of realization of shareholders' rights

Three aspects of shareholders' rights, board of directors, information disclosure and transparency, inspection of impact of internal corporate structure reform on enterprise performance

Target and operator responsibility system, function and composition of board of directors, execution system of top operators, communications and transparency among shareholders

Shareholders' rights, board directors' quality, effectiveness of internal control Shareholders' rights, structure of board of directors and committees, procedures of board of directors and committees, disclosure to investors, equality of ownership

Structure, independence and responsibilities of board of directors; equality for small shareholders; transparency and disclosure; stakeholder's role, rights and relations; shareholders' rights

Composition of board of directors(supervisors), equity structure, management participation and second largest shareholders, excess related transaction, extent of large shareholders stepping in the stock market

Transparency and disclosure (including internal monitoring), board of directors accountability, social responsibility, equity structure and degree of concentration, shareholders' rights, compensation of management levels, enterprise behaviors Promises of corporate governance, results and responsibilities of board of directors, control over environment and procedures, information disclosure and transparency, treatment to small shareholders

Corporate governance research center of Shareholders' rights, equal treatment to shareholders, stakeholders' role in world economy and politics institute of corporate governance, information disclosure and transparency, responsibilities Chinese academy of social science of board of directors and of board of supervisors Controlling shareholders, board of directors, board of supervisors, managementlevels, information disclosure, stakeholders

Source: Chinese corporate governance evaluation report issued by CACG at Nankai University (2016) 
market situation, and development conditions of Chinese companies can a suitable CGI system with Chinese characteristics and scientific methods be developed.

Based on field research and several discussions, ERG of CACG at Nankai University launched the Chinese corporate governance valuation indicator system of listed companies, which consisted of over 80 indicators in April 2003, and officially issued CCGI ${ }^{\mathrm{NK}}$ (known as the "barometer" of China's corporate governance of listed companies) in February 2004 for the first time and annually after that. CCGI ${ }^{\mathrm{NK}}$ fully considers the special aspects of China's corporate governance environment.

\subsection{Relevant researches of corporate governance index}

Corporate Governance Evaluation aims to provide references and guidelines for corporate governance research and practices. Scholars have applied various methods to establish CGI and conducted studies on the indicators of corporate governance in different dimensions.

$\mathrm{CACG}^{\mathrm{NK}}(2003 \mathrm{a}, 2003 \mathrm{~b})$ studied the practice and theoretical research development of corporate governance, which worked as the basis of the proposal of Corporate Governance Evaluation Index System (CCGI ${ }^{\mathrm{NK}}$ ). Then, the Project Team of China Academy of Corporate Governance of Nankai University (2004a, 2004b) conducted empirical studies to analyze the status of corporate governance of CLC. With the publication of CCGI ${ }^{\mathrm{NK}}$, many scholars found that there was a positive relationship between the index and corporate performance. $\mathrm{Li}$ and Tang (2006) found that CCGI ${ }^{\mathrm{NK}}$ of CLC had a significant positive impact on a series of financial indicators. Li et al. (2012) argued that high-level corporate governance could reduce investment risk of stocks. Based on the evaluation results of CCGI ${ }^{\mathrm{NK}}$, Hao et al. (2016) chose financial institutions as a sample to test the association between corporate governance and financial performance. They found that the improvement of corporate governance positively influenced financial performance and risk control of financial institutions, but the finding was true only in the dimension of board of directors.

Except for CCGI ${ }^{N K}$, other scholars also attempted to develop CGI. For example, Bai et al. (2005) combined internal and external governance mechanisms and established G-Index to evaluate corporate governance. Meanwhile, Lu et al. $(2014,2016)$ evaluated the quality of corporate governance from four aspects, i.e. ownership structure and shareholder rights, the operation of board of directors and supervisors, information disclosure and compliance, and incentives and constraints of the management level. They also found that there was a positive correlation between corporate governance and corporate performance. Han et al. $(2015,2016)$ established a CGI, including board of directors governance, management level governance, shareholder governance and meeting governance. Based on the CGI, they tested the positive impacts of corporate governance on long-term debt and financial performance. $\mathrm{Fu}$ (2016) built a set of CGI that consisted of equity governance, board of directors governance and executives' incentives and proposed that corporate governance promoted the creation of human capital value. Fang and Jin (2013) applied supervision and incentive as indicators to test the negative impact of corporate governance on inefficient investment.

In terms of specific indicators, the majority of research focused on board of directors, board of supervisors, management level, ownership structure, and stakeholders. For example, Li and Wang (2005) evaluated the governance performance of board of supervisors on the basis of relevant theoretical and practical research. Li and Tang (2005) developed stakeholders' governance index and evaluated the status of stakeholders' protection in light of the stakeholder theory. Shen et al. (2009) summarized the governance status of CLC from previous studies in four aspects, i.e. large shareholders, board of directors, management level and legal protection of investor. Wang and Liu (2009) took corporate governance factors into account comprehensively, which laid a foundation to evaluate the efficiency of 
NBRI

9,4

corporate governance through DEA model. In addition, there were other studies on the development of indexes from different dimensions (Gao et al., 2014). Besides, the relationship between corporate governance and corporate financing problems had also drawn great attention. From the perspective of information disclosure, Cheng et al. (2012) suggested that external financing played an intermediary role between financial information and investment efficiency. Wang and Li (2014) augured that stakeholder governance could effectively alleviate corporate financing constraints.

The G Index developed by Gibson (2003) was considered a milestone in the field of corporate governance evaluation. They developed the G Index based on the 24 provisions of corporate governance proposed by Investor Responsibility Research Center (IRRC). Then, Lao and Lin (2016) applied the same $G$ Index to verify the positive relationship between shareholders' rights and corporate value. Bebchuk et al. $(2005,2008)$ analyzed the G Index and further developed Entrenchment Index (E Index), which was positively related to stock returns and corporate value. $\mathrm{G}$ Index and $\mathrm{E}$ Index were widely applied to test the relationship between corporate governance and stock returns or corporate value. For example, Cremers and Ferrell (2009) argued that good corporate governance had a positive impact on corporate value by taking the two indexes as indicators. Using the same two indexes, Bebchuk et al. (2013) drew inconsistent conclusions on the relationship between corporate governance and abnormal stock returns during different periods. According to the 64 corporate governance characteristics of Global Management Institution (GMI), Ammann et al. (2011) built a set of CGI, which was applied to the research of multinational corporate governance evaluation. Furthermore, other scholars also developed CGIs from different dimensions according to the situation of their own countries (Das, 2012; Al-Malkawi et al., 2014; Nadarajah et al., 2016; Ararat et al., 2017; Li et al., 2017).

In addition to the index developed by scholars, many foreign evaluation institutions also built and released their own CGIs. For example, ISS established their CGI that included various factors, such as the structure and composition of board of directors and its main committees, companies' regulations, compensation of management level and directors, financial performance, corporate governance practices and so on. The CGI developed by GMI mainly focused on information transparency and disclosure, accountability of the board of directors, corporate social responsibility, equity structure and equity concentration, shareholder rights, management compensation, and corporate behaviors. Based on the above two CGIs, many studies had been undertaken to examine the relationship between corporate governance and corporate value, stock returns, equity capital costs and financial risks (Chhaochharia and Laeven, 2009). Besides, Kara and Erdur (2014) used stakeholder subindicators from the CGI (XKURY) issued by the Borsa Istanbul Stock Transaction to conduct their research. They found that corporate social responsibility has a significant positive impact on corporate value and financial performance. Kurt, Bener and Yusuf (2014) found a positive correlation between the XKURY index and the long-term stock returns. Moreover, Aydin and Ozcan (2015) used XKURY index to carry on their study and found that companies with good financial performance demonstrated higher levels of corporate governance.

\section{Development and composition of corporate governance index of Chinese listed company}

3.1 Development of corporate governance index of Chinese listed company

The development of CGI of CLC advanced gradually in a dynamic process. Specifically, there were four phases.

Phase 1: Research, organize and formulate China's corporate governance principles. With the support of China Society of Economic Reform, ERG launched the China's Corporate Governance Principles in 2001, which was absorbed and borrowed by the CSRC's Corporate 
Governance Rules for CLCs and Corporate Governance Principles in East Asia Region (formulated by the PECC), providing a reference standard for building a corporate governance evaluation indicator system.

Phase 2: Construct the corporate governance evaluation indicator system of CLC. After two years of surveys, ERG issued the Corporate Governance Research Report of Enterprises with Foreign Investment in China at the 1st Corporate Governance International Seminar in November 2001. In April 2003, after repeated revisions, the CGI system of CLC was published. At the 2nd Corporate Governance International Seminar, ERG sought opinions from experts

Chinese listed companies around the world and considered early research results and suggestions from corporate governance experts to reduce to six dimensions of a CGI system, which included shareholders governance index, board of directors governance index, board of supervisors governance index, management-levels index, information disclosure index and stakeholder governance index.

Phase 3: Officially launch the CGI of CLC and China's Corporate Governance Evaluation Report. Based on the evaluation indicator system and evaluation standards, the CGI of CLC was built and the China's Corporate Governance Evaluation Report was issued for the first time in 2004. The report used the CGI to produce a full and quantified evaluation and analysis of a large number of sampled companies for the first time. The report has been issued annually from then.

Phase 4: Apply the corporate governance evaluation system of CLC. Academically, the corporate governance evaluation system provides a platform for following research. ERG received support from a major project of the Natural Science Foundation of China and a major bidding project of The National Social Science Fund of China. The report was also published by Commercial Press, Higher Education Press and International Press. In addition, the report provided support for the regulatory work of authorities and guided enterprises to improve corporate governance levels. The CGI has also been published in the "CCTV China's Most Valuable Listed Companies of the Year". The CCTV Financial 50 Index (399550) went public on Shenzhen Stock Exchange on 6th June 2012. This index included five dimensions of innovation, growth, returns, governance, and social responsibility as the investigation criteria. It also set up a new benchmark for value investment, among which, ERG developed the governance dimension. The index was applied on the corporate governance status sampling evaluation of Chinese enterprises at the UN Trade Development Meeting and by the World Bank bidding project. From October 30th to 1st November 2007, the index was presented at the ISAR Panel 24 meeting at the invitation of the UN Trade Development Meeting. This index was also applied to the development and research related to the board of directors of solely state-owned, centrally administered enterprises of state-owned Assets Supervision and Administration Commission (SASAC) and the "Chinese SMEs economic development index" launched by an authorized project of the National Development and Reform Commission (NDRC). In 2007, ERG was entrusted by the China Insurance Regulatory Commission (CIRC) to design a corporate governance evaluation criteria system for insurance companies. In 2008, SASAC delegated ERG to evaluate the corporate governance status of centrally administered SOE holding companies. ERG has also developed China's CGI database, researched and developed China's corporate governance stock price index, and designed China's corporate governance scoring card.

\subsection{Composition of corporate governance index of Chinese listed company}

Based on the characteristics of the corporate environment of CLC, ERG reviewed theoretical corporate governance research, corporate governance principles, various corporate governance evaluation systems, and a large number of empirical research and case study. The group then designed the corporate governance evaluation system of CLC in 2003 and 
NBRI

9,4

446

issued the China's Corporate Governance Evaluation Report and CGI for CLCs in 2004. The research group optimized the system in 2004 and 2005 by properly adjusting the six dimensions of evaluation indicators, after widely seeking opinions and feedback. Through empirical research on the corporate governance of listed companies, the group adjusted some non-significant indicators. By conducting corporate governance evaluations on companies, the group continued to validate the effectiveness of the system and optimize it. The group introduced new research thoughts about corporate governance such as stakeholders and sought suggestions from various parties. They paid close attention to changes in the corporate governance environment and made corresponding updates in the evaluation system in a timely manner.

The final version of the corporate governance evaluation indicator system is shown in Table II. The indicator system is the basis of CGI. Considering that different environments require a different CGI system, the CGI of CLC reflects many important features of the Chinese market. This evaluation indicator system is based on the corporate governance environment, as faced by CLC. It emphasizes companies' internal corporate governance mechanisms and focuses on information disclosure, protection of the interests of small and medium shareholders, independence of listed companies, independence of the board of directors and participation in corporate governance by the board of supervisors. The system includes six dimensions of shareholders' rights and controlling shareholders, board directors and the board of directors, board supervisors and the board of supervisors, management, information disclosure and stakeholders, with 19 secondary factors and over 80 evaluation indicators. Altogether, the evaluation system considers a full and systematic evaluation of the corporate governance status of CLC.

\begin{tabular}{|c|c|c|}
\hline $\begin{array}{l}\text { Index } \\
\text { (target level) }\end{array}$ & Six dimensions (rule level) & Factors (factor level) \\
\hline $\mathrm{CCGI}^{\mathrm{NK}}$ & $\begin{array}{l}\text { Board of supervisors governance } \\
\left(\mathrm{CCGI}_{\mathrm{BOS}}^{\mathrm{NK}}\right) \\
\text { Management-level governance } \\
\left(\mathrm{CCGI} \mathrm{TOP}_{\mathrm{TK}}\right) \\
\text { Information disclosure } \\
\left(\mathrm{CCGI}_{\mathrm{ID}}^{\mathrm{NK}}\right) \\
\text { Stakeholders governance } \\
\left(\mathrm{CCGI}_{\mathrm{STH}}^{\mathrm{NK}}\right)\end{array}$ & $\begin{array}{l}\text { Independence of listed companies } \\
\text { Related transaction of listed companies } \\
\text { Protection on rights and interests on small and medium } \\
\text { shareholders } \\
\text { Rights and obligations of board directors } \\
\text { Operational efficiency of board of directors } \\
\text { Organizational structure of board of directors } \\
\text { Compensation of board directors } \\
\text { Independent director system } \\
\text { Operational status of board of supervisors } \\
\text { Scale and structure of board of supervisors } \\
\text { Capability of board supervisors } \\
\text { Appointment and dismissal system of management- } \\
\text { level } \\
\text { Execution guarantee of management-level } \\
\text { Incentives and constraints of management-level } \\
\text { Reliability of information disclosure } \\
\text { Relevance of information disclosure } \\
\text { Promptness of information disclosure } \\
\text { Participation extent of stakeholders } \\
\text { Coordination extent of stakeholders }\end{array}$ \\
\hline Source: $\mathrm{CAC}$ & at Nankai University & \\
\hline
\end{tabular}

Table II.

Corporate governance evaluation indicator system of CLC

Source: CACG at Nankai University 
3.3 Evaluation samples of the index over the years

Since the CGI of CLC was issued in 2004, ERG evaluated the status of corporate governance of 931 companies in 2003, 1,149 in 2004. The number of companies in the sample was relatively stable from 2004 to 2009 . As the number of listed companies increased since 2010, the number of companies in the evaluation sample also increased, up from 1,261 in 2009 to 2,470 in 2013, and exceeds 3,000 companies in 2017. Please see Figure 1 for detailed information. It is noteworthy that the regulatory authorities require listed companies to issue their annual reports of the previous year by the end of April of the current year. companies Therefore, the CGI of 2017 actually reflected the status of companies in 2016.

\section{Analysis of corporate governance of Chinese listed company}

\subsection{Data and sample selection}

The data of the CGI of CLC in 2017 were from the public information (company website, chinfo.com.cn, CSRC, websites of Shanghai and Shenzhen Stock Exchanges, etc.) until 30th April 2017, the Xenophon CCER database, CSMAR and WIND. Based on the basic principles of information integrity and no containment of abnormal data, we identified 3,031 valid companies in the sample, among which, 1,639 were from the main board, including 60 financial institutions and 1,579 non-financial institutions, 822 were from small and medium enterprises (SME) board, including 7 financial institutions and 815 non-financial institutions, 570 were from ChiNext. It is worth noting that, considering the special corporate governance of financial institutions, SME board and ChiNext companies, we conducted a separate analysis by combining financial institutions from the main board and SME board as one sector. Therefore, the total of companies in the sample was 3,031, among which, 1,579 were from the main board, 815 are from the SME board, 570 from ChiNext and 67 from the financial and insurance sector. A detailed analysis of each sector is shown in the following sections.

4.1.1 Sample description. In the 2017 sample, the mean of the CGI of CLC was 62.67, up by 0.18 from 62.49 in 2016. Table III reports sample descriptive statistics.

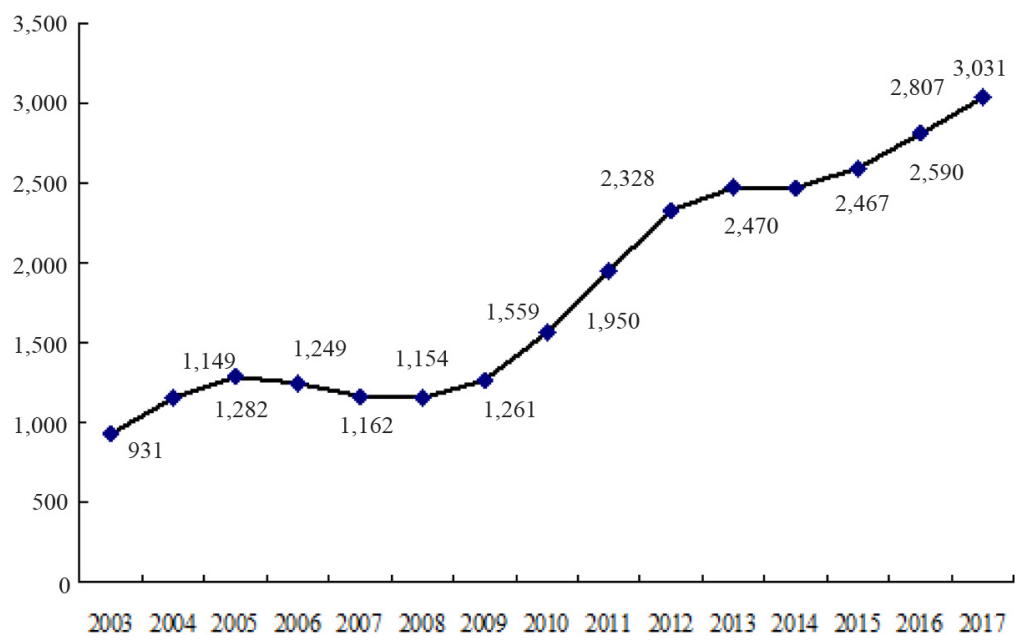

Source: Corporate governance database at Nankai University

Figure 1.

Number of Companies in the corporate governance evaluation system 
NBRI

9,4

448

Statistic indicator

CGI

Mean

62.67

Median

62.77

Standard deviation

3.29

Variance

10.82

Measure of skewness

$-0.19$

Kurtosis

$-0.13$

Range

20.53

Minimum

51.37

Table III.

Maximum

71.90

Descriptive statistics of CGI of CLC

Source: Corporate governance database at Nankai University.

As shown in Table III, the maximum CGI of 2017 was 71.90 , the minimum was 51.37 and the standard deviation was 3.29. Figure 2 shows the distribution graph.

Among the 3,031 sampled companies, no company was in the categories of $\mathrm{CCGI}^{\mathrm{NK}} \mathrm{I}$ and CCGI $^{\mathrm{NK}} \mathrm{II}$ and 21 companies fell in CCGI ${ }^{\mathrm{NK}} \mathrm{III}$. In total, 2,370 companies reached CCGI ${ }^{\mathrm{NK}} \mathrm{IV}$, accounting for 78.19 per cent, a significant increase from 72.64 per cent in 2016. 640 companies reached $\mathrm{CCGI}^{\mathrm{NK}}$, accounting for 21.12 per cent, also a significant decrease from 25.90 per cent in 2016 . No company had a score below 50 . The percentage of companies with scores lower than 50 was 0.18 per cent in 2016, 0.04 per cent in 2015, 0.12 per cent in 2014, 0.16 per cent in 2013, 0.21 per cent in 2012, 0.67 per cent in 2011 and 3.33 per cent in 2010.

4.1.2 Analysis by industry. There were differences of CGI among different industries. The means of the index for the industries of health and social work, scientific research and technology services, information transmission, software and information technology services, and finance were relatively high, at 64.00, 63.74, 63.72, and 63.62, respectively.

Figure 2.

Distribution graph

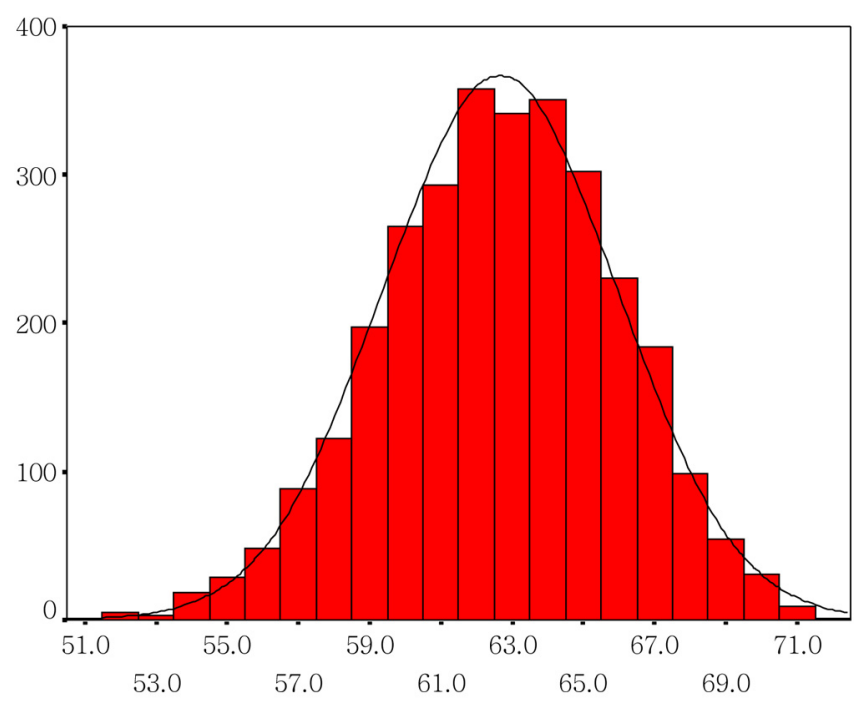

Source: Corporate governance database at Nankai University 
However, the means for accommodation and catering, wholesale and retail, leasing and business services, real estate, synthesis, and mining companies were relatively low, at 61.83, $61.47,61.43,60.99,60.96$ and 60.70 , respectively. Compared with previous years, the ranking of the CGI in various industries changed in 2017. Table V shows the industry composition of sampled companies.

4.1.3 Analysis by controlling shareholder. As shown in Table VI, companies in the lowest quantities were "employ stock committee holding", "social group holding", "collectiveowned holding", "other types" and "foreign-owned holding", with the number of companies at 4,13, 18, 30 and 45, respectively. "State-owned holding" and "private holding" had more companies, 1,044 and 1,877 , respectively.

The mean of CGI of "other types" was the highest, at 63.97, followed by "private holding" and "foreign-owned holding", at 63.12 and 62.85, respectively. The mean of "collectiveowned holding" was 61.92, "state-owned holding" was 61.88, and "employ stock committee holding" was 60.52. The mean of "social group holding" was 58.14, the lowest of all types. The index mean of "private holding" CLC was higher than "state-owned holding" CLC.

4.1.4 Analysis by geographical area. The results are shown in Table VII. Similar to previous years, developed areas such as Guangdong, Zhejiang, Jiangsu, Beijing and Shanghai had the highest numbers of companies, while underdeveloped areas in the west had small numbers of companies. This reflected the relationship between economic development level and the number of listed companies. The means of Guangdong, Henan, Jiangsu, Zhejiang, Beijing, Hunan, Hebei, Anhui, and Shandong were higher, at 63.77, 63.36, 63.09, 63.09, 63.01, 62.98, 62.88, 62.83 and 62.73, respectively, while those of Heilongjiang, Hainan, Qinghai, Ningxia and Shanxi were around 60, reaching 60.31, 60.20, 60.03, 59.89 and 59.81, respectively.

4.1.5 Analysis by board types. We divided sampled companies based on the type of market boards, among which, the mean of ChiNext CGI was 64.49, ranking the first. The SME board was 63.81, the financial and insurance industries was 63.62, while just same as the 2016 condition, the governance index of main board companies is the lowest of 61.38 , as shown in Table VIII.

4.1.6 Analysis by year. The mean of the 2017 CGI was 62.67, and those of 2012, 2013, 2014, 2015 and 2016 were 60.60, 60.76, 61.46, 62.07 and 62.49, respectively (Table IX). By comparing the overall corporate governance situation of CLC of these consecutive years, the overall CGI increased.

Among the sub-indexes, the mean of shareholder governance index was 65.00 in 2017, down by 1.04 from 66.04 in 2016. The board of directors $(\mathrm{BoD})$ governance index increased gradually. As the core of corporate governance, the board of directors $(\mathrm{BoD})$ increased to

\begin{tabular}{|c|c|c|c|c|}
\hline \multirow{2}{*}{\multicolumn{2}{|c|}{ Grade of CGI of CLC }} & \multicolumn{2}{|c|}{ Distribution } & \\
\hline & & \multirow{2}{*}{$\frac{\text { No. of companies }}{0}$} & \multirow{2}{*}{$\begin{array}{c}(\%) \\
0\end{array}$} & \\
\hline $\mathrm{CCGI}^{\mathrm{NK}} \mathrm{I}$ & $90-100$ & & & \\
\hline $\mathrm{CCGI}^{\mathrm{NK}} \mathrm{II}$ & $80-90$ & 0 & 0 & \\
\hline $\mathrm{CCGI}^{\mathrm{NK}} \mathrm{III}$ & $70-80$ & 21 & 0.69 & \\
\hline $\mathrm{CCGI}^{\mathrm{NK}} \mathrm{IV}$ & $60-70$ & 2,370 & 78.19 & \\
\hline $\mathrm{CCGI}^{\mathrm{NK}}$ & $50-60$ & 640 & 21.12 & \\
\hline $\mathrm{CCGI}^{\mathrm{NK}}$ & Below 50 & 0 & 0 & \\
\hline \multicolumn{2}{|l|}{ Total } & 3,031 & 100.00 & Table IV. \\
\hline \multicolumn{4}{|c|}{ Source: Corporate governance database at Nankai University } & CGI of CLC \\
\hline
\end{tabular}

Chinese listed companies

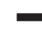


NBRI

9,4

\begin{tabular}{|c|c|c|c|c|c|c|c|c|}
\hline Industry & $\begin{array}{l}\text { No. of } \\
\text { companies }\end{array}$ & $(\%)$ & Mean & Median & $\mathrm{SD}$ & Range & Min & Max \\
\hline $\begin{array}{l}\text { Agriculture, forestry, animal } \\
\text { husbandry and fishery }\end{array}$ & 45 & 1.48 & 61.89 & 61.88 & 3.10 & 14.15 & 54.97 & 69.12 \\
\hline Extractive industry & 75 & 2.47 & 60.70 & 60.44 & 2.68 & 12.10 & 54.97 & 67.06 \\
\hline Manufacturing industry total & 1,895 & 62.52 & 62.96 & 63.17 & 3.29 & 19.78 & 52.12 & 71.90 \\
\hline $\begin{array}{l}\text { Production and supply } \\
\text { industry of electricity, gas } \\
\text { and water }\end{array}$ & 97 & 3.20 & 61.98 & 61.80 & 2.95 & 13.88 & 55.55 & 69.42 \\
\hline Construction industry & 88 & 2.90 & 62.19 & 62.41 & 3.17 & 18.21 & 51.59 & 69.80 \\
\hline $\begin{array}{l}\text { Wholesale and retailing trade } \\
\text { industry }\end{array}$ & 156 & 5.15 & 61.47 & 61.56 & 3.45 & 17.16 & 51.56 & 68.72 \\
\hline $\begin{array}{l}\text { Transportation and storage } \\
\text { industry }\end{array}$ & 89 & 2.94 & 62.07 & 62.18 & 2.63 & 10.29 & 56.61 & 66.90 \\
\hline Accommodation and catering & 11 & 0.36 & 61.83 & 62.04 & 4.32 & 14.23 & 53.75 & 67.98 \\
\hline $\begin{array}{l}\text { Information transmission, } \\
\text { software and information } \\
\text { technology services }\end{array}$ & 203 & 6.70 & 63.72 & 64.01 & 3.03 & 15.48 & 54.30 & 69.78 \\
\hline $\begin{array}{l}\text { Financial and insurance } \\
\text { industry }\end{array}$ & 67 & 2.21 & 63.62 & 63.60 & 3.18 & 12.31 & 57.20 & 69.51 \\
\hline Real estate industry & 125 & 4.12 & 60.99 & 60.48 & 3.28 & 17.59 & 51.37 & 68.97 \\
\hline $\begin{array}{l}\text { Leasing and business } \\
\text { services }\end{array}$ & 42 & 1.39 & 61.43 & 61.37 & 3.10 & 13.41 & 54.95 & 68.37 \\
\hline $\begin{array}{l}\text { Scientific research and } \\
\text { technical services }\end{array}$ & 27 & 0.89 & 63.74 & 63.77 & 3.10 & 11.83 & 59.46 & 71.29 \\
\hline $\begin{array}{l}\text { Water, Environment and } \\
\text { Public Facilities Management }\end{array}$ & 33 & 1.09 & 62.57 & 62.73 & 2.98 & 13.52 & 56.48 & 70.00 \\
\hline Education & 3 & 0.10 & 62.82 & 62.70 & 2.47 & 4.94 & 60.41 & 65.35 \\
\hline Social service industry & 7 & 0.23 & 64.00 & 64.73 & 4.68 & 12.83 & 58.56 & 71.39 \\
\hline $\begin{array}{l}\text { Communication and culture } \\
\text { industry }\end{array}$ & 45 & 1.48 & 62.21 & 62.32 & 2.43 & 12.18 & 55.78 & 67.95 \\
\hline Synthesis & 23 & 0.76 & 60.96 & 61.76 & 2.72 & 9.25 & 55.50 & 64.75 \\
\hline Total & 3,031 & 100.00 & 62.67 & 62.77 & 3.29 & 20.53 & 51.37 & 71.90 \\
\hline
\end{tabular}

Table V.

Comparison by industry

\section{0}

husbandry and fishery

Extractive industry

60.70

60.4

19.78

Production and supply

$y$ of electricity, gas

Construction industry

Wholesale and retailing trade

industry

Accommodation and catering

technology services

industry

Real estate industry

Leasing and business

Scientific research and

Public Facilities Management

Education

Social service industry

Communication and culture

Synthesis

Source: Corporate governance database at Nankai University

\begin{tabular}{|c|c|c|c|c|c|c|c|c|}
\hline Controlling shareholder' Type & $\begin{array}{c}\text { No. of } \\
\text { companies }\end{array}$ & $(\%)$ & Mean & Median & $\mathrm{SD}$ & Range & Min & Max \\
\hline State-owned holding & 1,044 & 34.44 & 61.88 & 61.82 & 3.16 & 19.48 & 51.69 & 71.17 \\
\hline Collective-owned holding & 18 & 0.59 & 61.92 & 61.45 & 3.78 & 15.97 & 55.24 & 71.21 \\
\hline Private holding & 1,877 & 61.93 & 63.12 & 63.34 & 3.25 & 20.53 & 51.37 & 71.90 \\
\hline Social group holding & 13 & 0.43 & 58.14 & 58.81 & 3.46 & 11.78 & 51.56 & 63.34 \\
\hline Foreign-owned holding & 45 & 1.48 & 62.85 & 63.03 & 2.96 & 14.91 & 54.34 & 69.24 \\
\hline Employ stock committee holding & 4 & 0.13 & 60.52 & 59.72 & 3.09 & 6.77 & 57.93 & 64.70 \\
\hline Other types & 30 & 0.99 & 63.97 & 64.02 & 3.36 & 13.66 & 55.85 & 69.51 \\
\hline Total & 3,031 & 100.00 & 62.67 & 62.77 & 3.29 & 20.53 & 51.37 & 71.90 \\
\hline
\end{tabular}

Table VI.

Comparison by controlling shareholder's type 


\begin{tabular}{|c|c|c|c|c|c|c|c|c|c|}
\hline Province & $\begin{array}{c}\text { No. of } \\
\text { companies }\end{array}$ & $(\%)$ & Mean & Median & $\mathrm{SD}$ & Range & Min & Max & companies \\
\hline Beijing & 282 & 9.30 & 63.01 & 63.06 & 3.13 & 18.01 & 52.83 & 70.84 & \\
\hline Tianjin & 45 & 1.48 & 61.77 & 61.79 & 2.98 & 12.75 & 55.46 & 68.21 & \\
\hline Hebei & 51 & 1.68 & 62.88 & 62.76 & 3.02 & 12.61 & 57.70 & 70.31 & \\
\hline Shanxi & 38 & 1.25 & 59.81 & 59.83 & 3.76 & 14.00 & 52.28 & 66.28 & \\
\hline Inner Mongolia & 25 & 0.82 & 61.03 & 60.71 & 3.60 & 13.64 & 53.93 & 67.57 & 451 \\
\hline Liaoning & 73 & 2.41 & 61.68 & 61.69 & 3.62 & 16.22 & 53.93 & 70.15 & \\
\hline Jilin & 41 & 1.35 & 61.47 & 61.18 & 3.50 & 14.87 & 54.20 & 69.07 & \\
\hline Heilongjiang & 35 & 1.15 & 60.31 & 60.34 & 2.54 & 12.15 & 53.40 & 65.55 & \\
\hline Shanghai & 237 & 7.82 & 61.98 & 62.00 & 3.47 & 19.17 & 51.37 & 70.54 & \\
\hline Jiangsu & 316 & 10.43 & 63.09 & 63.15 & 3.12 & 16.77 & 54.53 & 71.29 & \\
\hline Zhejiang & 327 & 10.79 & 63.09 & 63.22 & 2.90 & 15.99 & 53.56 & 69.55 & \\
\hline Anhui & 93 & 3.07 & 62.83 & 62.81 & 3.25 & 16.25 & 54.97 & 71.21 & \\
\hline Fujian & 106 & 3.50 & 62.58 & 62.73 & 3.00 & 13.88 & 55.27 & 69.14 & \\
\hline Jiangxi & 37 & 1.22 & 62.35 & 63.02 & 3.34 & 12.39 & 55.57 & 67.95 & \\
\hline Shandong & 169 & 5.58 & 62.73 & 62.20 & 3.28 & 15.23 & 55.17 & 70.40 & \\
\hline Henan & 74 & 2.44 & 63.36 & 63.46 & 3.04 & 15.16 & 54.81 & 69.97 & \\
\hline Hubei & 94 & 3.10 & 62.47 & 62.79 & 3.01 & 15.44 & 53.91 & 69.35 & \\
\hline Hunan & 84 & 2.77 & 62.98 & 63.04 & 3.27 & 15.61 & 55.78 & 71.39 & \\
\hline Guangdong & 471 & 15.54 & 63.77 & 63.91 & 2.98 & 18.15 & 53.75 & 71.90 & \\
\hline Guangxi & 36 & 1.19 & 61.61 & 62.12 & 3.12 & 13.05 & 54.30 & 67.35 & \\
\hline Hainan & 28 & 0.92 & 60.20 & 60.32 & 3.51 & 15.92 & 51.56 & 67.48 & \\
\hline Chongqing & 43 & 1.42 & 61.83 & 61.97 & 3.46 & 12.89 & 56.07 & 68.97 & \\
\hline Sichuan & 110 & 3.63 & 62.18 & 62.26 & 3.71 & 19.05 & 51.69 & 70.73 & \\
\hline Guizhou & 23 & 0.76 & 62.37 & 62.45 & 3.88 & 15.09 & 54.34 & 69.42 & \\
\hline Yunnan & 32 & 1.06 & 62.46 & 62.90 & 3.93 & 15.74 & 54.26 & 70.00 & \\
\hline Tibet & 14 & 0.46 & 61.65 & 61.12 & 2.47 & 8.00 & 57.95 & 65.94 & \\
\hline Shaanxi & 45 & 1.48 & 61.94 & 61.99 & 3.15 & 13.22 & 54.95 & 68.17 & \\
\hline Gansu & 30 & 0.99 & 61.71 & 61.87 & 3.26 & 12.17 & 55.26 & 67.42 & \\
\hline Qinghai & 12 & 0.40 & 60.03 & 60.20 & 3.29 & 12.33 & 52.12 & 64.45 & \\
\hline Ningxia & 12 & 0.40 & 59.89 & 58.71 & 3.87 & 11.35 & 54.92 & 66.28 & \\
\hline Xinjiang & 48 & 1.58 & 61.55 & 61.43 & 3.41 & 17.00 & 53.17 & 70.17 & \\
\hline Total & 3,031 & 100.00 & 62.67 & 62.77 & 3.29 & 20.53 & 51.37 & 71.90 & Table VII. \\
\hline Source: Corpo & overnance & ase a & ai U & & & & & & $\begin{array}{l}\text { comparison by } \\
\text { geographical area }\end{array}$ \\
\hline
\end{tabular}

\begin{tabular}{|c|c|c|c|c|c|c|c|c|c|}
\hline Market board type & $\begin{array}{c}\text { No. of } \\
\text { companies }\end{array}$ & $(\%)$ & Mean & Median & $\mathrm{SD}$ & Range & Min & Max & \\
\hline Main board & 1,579 & 52.10 & 61.38 & 61.40 & 3.14 & 19.80 & 51.37 & 71.17 & \\
\hline SME board & 815 & 26.89 & 63.81 & 63.92 & 2.88 & 16.62 & 55.28 & 71.90 & \\
\hline ChiNext & 570 & 18.81 & 64.49 & 64.52 & 2.69 & 16.22 & 55.17 & 71.39 & \\
\hline $\begin{array}{l}\text { Financial and insurance } \\
\text { industries }\end{array}$ & 67 & 221 & 6362 & 6360 & 3.18 & 1231 & 5720 & 69.51 & \\
\hline Total & 3,031 & 100.00 & 62.67 & 62.77 & $\begin{array}{l}3.10 \\
3.29\end{array}$ & 20.53 & 51.37 & 71.90 & $\begin{array}{l}\text { Table VIII. } \\
\text { Comparison by board }\end{array}$ \\
\hline
\end{tabular}


NBRI

9,4

\section{2}

64.28 in 2017 after exceeding 60 in 2010 for the first time. The newly issued Corporate Law might have strengthened the function and power of board of directors (BoD) and board of supervisors (BoS). Management-level governance and information disclosure also increased. The stakeholder issue gradually attracted attention from listed companies and increased steadily, in spite of a slight decline in 2003. Since 2010, the index rose significantly. However, the mean index in 2013 slightly decreased.

\subsection{Evaluation of top 100 companies}

4.3.1 Descriptive statistics. The mean of the CGI of top 100 companies was 69.41. Compared with Table III, we found that the mean was significantly higher than the whole sample.

4.3.2 Performance of top 100 companies. We selected ten financial indicators that reflected profitability and agency cost of listed companies. The comparison results are shown in Table XI. The indicators that reflected the profitability of listed companies included: $\mathrm{ROA}(\mathrm{A})=$ net profit/total assets balance; $\mathrm{ROA}(\mathrm{B})=$ net profit/average total assets balance, average balance of the total assets $=$ (ending balance of total assets + beginning balance of total assets $) / 2 ; \operatorname{ROA}(\mathrm{C})=$ net profit/total assets average balance, average balance of the total assets $=$ (ending balance of total assets + ending balance of total assets of previous period) $/ 2 ; \operatorname{ROE}(\mathrm{A})=$ net profit/total equity balance; $\mathrm{ROE}(\mathrm{B})=$ net profit/average total equity balance, average balance of the total equity $=$ (ending balance of total equity + beginning balance of total equity $) / 2 ; \operatorname{ROE}(\mathrm{C})=$ net profit/total equity average balance, average balance of the total equity $=$ (ending balance of total equity + ending balance of total equity of previous period)/2; return on capital $=$ (net profit + financial expenses)/(total assets - current liabilities + bills + short-term loans + long-term liabilities due in a year);

\begin{tabular}{lllllll}
\hline Type of index & 2012 & 2013 & 2014 & 2015 & 2016 & 2017 \\
\hline CGI & 60.60 & 60.76 & 61.46 & 62.07 & 62.49 & 62.67 \\
Shareholders governance index & 61.20 & 62.89 & 64.28 & 65.08 & 66.04 & 65.00 \\
Board of Directors governance index & 61.21 & 61.74 & 63.38 & 63.48 & 64.11 & 64.28 \\
Board of Supervisors governance index & 57.35 & 57.38 & 57.99 & 58.54 & 58.76 & 58.78 \\
Management-level governance index & 57.27 & 57.21 & 57.12 & 57.80 & 58.01 & 58.92 \\
Information disclosure index & 63.14 & 63.18 & 63.29 & 64.27 & 64.53 & 65.04 \\
Stakeholders governance index & 63.22 & 61.46 & 61.84 & 62.51 & 62.68 & 62.92
\end{tabular}

Table IX.

Comparison by year Source: Corporate governance database at Nankai University

\begin{tabular}{lcccrrr}
\hline Type of index & Mean & Median & SD & Range & Min & Max \\
\hline CGI & 69.41 & 69.19 & 0.79 & 3.44 & 68.46 & 71.90 \\
Shareholders governance index & 72.73 & 72.90 & 5.46 & 33.40 & 52.50 & 85.90 \\
BoD governance index & 65.86 & 65.89 & 2.43 & 16.00 & 61.31 & 77.32 \\
BoS governance index & 61.42 & 60.32 & 5.59 & 23.60 & 51.18 & 74.78 \\
Management-level governance index & 66.49 & 66.85 & 4.63 & 25.85 & 52.15 & 78.00 \\
Information disclosure index & 74.51 & 74.51 & 4.78 & 20.52 & 63.62 & 84.14 \\
Stakeholders governance index & 76.37 & 79.00 & 8.64 & 36.03 & 52.42 & 88.45 \\
Source: Corporate governance database of the Nankai University & & & & \\
\hline
\end{tabular}

Table X.

Descriptive statistics 


\begin{tabular}{lccr}
\hline Financial index & Top 100 Companies & Other companies & $\begin{array}{r}\text { Chinese listed } \\
\text { companies }\end{array}$ \\
\cline { 1 - 3 } ROA(A) & 0.0524 & 0.0392 & \\
ROA(B) & 0.0585 & 0.0427 & \\
ROA(C) & 0.0577 & 0.0392 & \\
ROE(A) & 0.0853 & 0.0646 & \\
ROE(B) & 0.0943 & 0.0655 & \\
ROE(C) & 0.0924 & 0.0607 & $\mathbf{4 5 3}$ \\
Return on capital & 0.0689 & 0.0598 & Table XI. \\
Long-term capital yield & 0.1050 & 0.0842 & Comparison of \\
Management fee rate & 0.1231 & 0.1386 & performance \\
Financial fee rate & 0.0099 & & \\
Source: Corporate Governance Database at Nankai University & & & \\
\hline
\end{tabular}

long-term capital yield $=$ (profit total + (finance expenses)/long-term capital, long-term capital = average balance non-current liabilities + owners' equity average balance $=($ beginning of non-current liabilities + ending of non-current liabilities $) / 2+$ (beginning of owners' equity + ending of owner's equity) $/ 2$.

There were two indicators of agency cost: management fee rate = management expense/ operating income; financial expenses= financial expenses/operating income. Overall, the performance indicators of top 100 companies were better than those of other companies.

\section{Conclusions}

\subsection{Summary}

Based on the above analyses, we draw ten conclusions about the CGI of CLC.

First, the level of corporate governance of CLC has been improved rapidly in the recent ten years, though it still requires further improvement. The overall corporate governance level increased from 2004, and despite a deviation in 2009, continued to increase and reached a record high in 2017.

Second, there are differences in corporate governance levels among CLC in different industries, controlling shareholders and areas.

Third, there are obvious differences among companies listed on different boards. The CGI of companies listed on ChiNext exceeded those of companies listed on small and medium board, as well as financial industries. Companies listed on the main board had the lowest score.

Fourth, the top 100 CLC with the highest CGI had better governance status than other sampled companies. These top 100 companies also had higher profitability and lower agency cost.

Fifth, the protection of the interests of small and medium shareholders and the development of related transactions are limited. Shareholder governance index in 2017 decreased from that in 2016. In addition, independence increased, protection of rights and interests of small and medium shareholders decreased and associated trading decreased. The reason may be the deterioration of protection of rights and interests of small and medium shareholders and related transactions.

Sixth, the board compensation system is the bottleneck of board governance. The subindexes of board governance were imbalanced, with board organizational structure at the higher end and board compensation system index at the lower end. 
NBRI

9,4

Seventh, the board of supervisors' governance has improved year after year, but the overall level is still low.

Eighth, the incentive and constraint mechanisms at the management-level have always been an issue with management-level governance.

Ninth, information disclosure is above average among all the dimensions of corporate governance. In particular, promptness shows the best performance, followed by reliability and relevance.

Tenth, the stakeholder governance level has improved substantially. This suggests that with the assimilation of the concept and consciousness of governance, CLC pay more attention to the relationship with stakeholders to build a more harmonious internal and external governance environment.

\subsection{Future directions}

Improving the quality of listed companies is a fundamental solution because these companies are the foundation of the stock market. Only when the quality of listed companies is improved can the stock market achieve healthy development (Cheng, 2007). There are two important indicators in evaluating the quality of listed companies, i.e. financial performance and corporate governance. Corporate governance is the foundation of the underlying system that supports financial performance. The evaluation results show that the corporate governance environment in China has been improving in the recent years, with the transformation from an administration focus to an economic focus. The corporate governance structure and mechanism based on rules, compliance and accountability have been assimilated so that enterprises are more active to explore governance models and innovations. Overall, China's corporate governance compliance has significantly increased, so does the level of corporate governance of CLCs. However, some governance mechanisms are yet to be developed because corporate governance is an important and long-term journey for enterprises.

\section{References}

Al-Malkawi, H., Pillai, R. and Bhatti, M.I. (2014), "Corporate governance practices in emerging markets: the case of GCC countries [J]", Economic Modelling, Vol. 38, pp. 133-141.

Ammann, M., Oesch, D. and Schmid, M.M. (2011), “Corporate governance and firm value: international evidence [J]", Journal of Empirical Finance, Vol. 18 No. 1, pp. 36-55.

Ararat, M., Black, B.S. and Yurtoglu, B.B. (2017), "The effect of corporate governance on firm value and profitability: time-series evidence from Turkey [J]”, Emerging Markets Review, Vol. 30, pp. 113-132.

Aydin, A.D. and Ozcan, A. (2015), "Corporate governance and firm performance: recent evidence from borsa Istanbul (BIST) corporate governance index (XKURY) [J]”, Research Journal of Finance and Accounting, Vol. 14 No. 6, pp. 198-204.

Bai, C.E., Liu, Q., Lu, Z., Song, M. and Zhang, J.X. (2005), “An empirical study on the governance structure of china's listed companies [J]", Economic Research Journal, Vol. 2, pp. 81-91. In Chinese)

Bebchuk, L.A. and Cohen, A. (2005), "The costs of entrenched boards [J]", Journal of Financial Economics, Vol. 78 No. 2, pp. 409-433.

Bebchuk, L., Cohen, A. and Ferrell, A. (2008), "What matters in corporate governance? [J]", The Review of financial Studies, Vol. 22 No. 2, pp. 783-827.

Bebchuk, L.A., Cohen, A. and Wang, C.C.Y. (2013), "Learning and the disappearing association between governance and returns [J]", Journal of financial economics, Vol. 108 No. 2, pp. 323-348. 
Cheng, S.W. (2015), Review and Prospect of China 's Stock Market: From 2002 to 2013 [M], Science Press, Beijing (in Chinese).

Cheng, X.S., Tan, Y.C. and Liu, J.M. (2012), "The non-financial information, the external financing, and the investment efficiency: a study based on the constraint of external systems [M]", Management World, Vol. 7, pp. 137-150 (in Chinese).

Chhaochharia, V. and Laeven, L. (2009), “Corporate governance norms and practices [J].”, Journal of Financial Intermediation, Vol. 18 No. 3, pp. 405-431.

Cremers, M. and Ferrell, A. (2009), "Thirty years of corporate governance: firm valuation and stock returns [J]", Revise and Resubmit at Journal of Finance,

Das, S.C. (2012), Corporate Governance in India: An Evaluation [M], PHI Learning, India.

Fang, H.X. and Jin, Y. (2013), Corporate Governance, Internal Control and Inefficient Investment: Theoretical Analysis and Empirical Evidences [J], Accounting Research, (7) (in Chinese).

Fu, C.R. (2016), "Corporate governance, ownership nature of the ultimate controller and the ValueAdded efficiency of intellectual Capital: empirical evidence from china's A-share listed firms [J].”, Journal of Shanxi University of Finance and Economics, Vol. 8 (in Chinese).

Gao, M.H., Su, R. and Fang, F. (2014), "The evaluation and validity test of board governance of chinese listed companies [J].", Economic Perspectives, Vol. 2 (in Chinese).

Gibson, M.S. (2003), "Is corporate governance ineffective in emerging markets? [J].”, Journal of Financial and Quantitative Analysis, Vol. 38 No. 1, pp. 231-252.

Han, S.Z. and Pan, Y. (2016), "Corporate governance level, ownership structure and debt contracts: empirical evidence from chinese A-share listed companies [J]", Journal of Northwest University (Philosophy and Social Sciences Edition, Vol. 46 No. 1 (in Chinese).

Han, S.Z., Pan, Y., and Zhang, X.M. (2015), The Level of Corporate Governance and Firm Performance: empirical Evidence from Chinese A-Share Listed Companies [J], China Economic Studies, Vol. 1 (in Chinese).

Hao, C., Cui, G.Y., Li, H.B. and Wang, L.X. (2016), "The effectiveness of corporate governance of chinese listed financial institutions: an empirical analysis based on 2008-2015 CCGINK [J]", Finance Forum, Vol. 3, pp. 64-71 (in Chinese).

Kara, E. and Erdur, D. (2014), "A. Analyzing the effects of corporate social responsibility level on the financial performance of companies: an application on BIST corporate governance index included companies [J]", International Journal of Management Economics and Business, Vol. 10 No. 23, pp. 227-227.

Kurt, G.G., Bener, G. and Yusuf, G. (2014), "The relationship between corporate governance and stock returns [J]", Dumlupinar University Journal of Social Science, Vol. 7, pp. 124-143.

Li, J., Yang, J. and Yu, Z.X. (2017), "Does corporate governance matter in competitive industries? Evidence from China [J]”, Pacific-Basin Finance Journal, Vol. 43 No. 6, pp. 238-255.

Li, W.A. and Tang, Y.J. (2005), "Governance mechanism of stakeholders, corporate governance index and corporate performance of china's listed companies [J]", Management World, Vol. 9, pp. 127-136 (In Chinese).

Li, W.A. and Tang, Y.J. (2006), “Corporate governance evaluation, corporate governance index and corporate performance-evidence from China's listed companies in 2003 [J]", China Industrial Economics, Vol. 4, pp. 98-107 (In Chinese).

Li, W.A. and Wang, S.Q. (2005), "Appraisal and empirical research about the governance of supervisor board of china's listed companies [J]", Nankai Business Review, Vol. 8, pp. 4-9 (In Chinese).

Li, W.A., Zhang, L.D. and Zhang, S. (2012), “Corporate governance, investors' heterogeneous belief and stock risk: empirical research on Chinese listed companies [J]", Nankai Business Review, Vol. 6, pp. 135-146 (in Chinese). 
NBRI

9,4

Lu, T., Zhong, J.Y., Ye, Y., Yu, H.J., Wu, G.D. and Dang, Y. (2014), "Research on governance of small and medium-sized listed companies in China [J]”, Academic Research, Vol. 6, pp. 64-71 (in Chinese).

Shen, Y.F., Xiao, M. and Lin, T. (2009), "Investor protection and firm Capital structure [J]", Economic Research Journal, Vol. 7, pp. 131-142 (In Chinese).

The Project Team of China Academy of Corporate Governance of Nankai University (2004), "An empirical analysis of corporate governance index and governance performance of listed companies in China [J]", Management World, Vol. 2, pp. 63-74 (in Chinese).

Wang, P.C. and Li, J.B. (2014), "Can stakeholder governance help enterprises relieve the financial constraints [J]", Journal of Shanxi University of Finance and Economics, Vol. 12 (in Chinese).

Wang, F.S. and Liu, S.Y. (2009), "Research on corporate governance premium based on simultaneous equations: how to test the validity of any corporate governance index [J]", Nankai Business Review, Vol. 5, pp. 151-160 (In Chinese).

\section{Further reading}

Nadarajah, S., Ali, S., Liu, B. and Huang, A. (2017), "Stock liquidity, corporate governance and leverage: new panel evidence [J]", Pacific-Basin Finance Journal, Forthcoming.

The Project Team of China Academy of Corporate Governance of Nankai University (2007), Research Report on Corporate Governance Evaluation of Chinese Listed Companies in 2003 [M]. Commercial Press (in Chinese).

The Project Team of China Academy of Corporate Governance of Nankai University (2007), Research Report on Corporate Governance Evaluation of Chinese Listed Companies in 2004 [M]. Commercial Press (in Chinese).

The Project Team of China Academy of Corporate Governance of Nankai University (2003), "A Study of Appraisal System of Corporate Governance for Chinese Listed Companies [J]", Nankai Business Review, Vol. 3, pp. 4-12 (in Chinese).

Tong, L. and Guoding, W. (2016), "Evaluation on the Governance of Listed Companies on SME and GEM Boards [J]", Directors and Boards, Vol. 3, pp. 36-40 (in Chinese).

\section{Corresponding author}

Weian Li can be contacted at: liweian@nankai.edu.cn

For instructions on how to order reprints of this article, please visit our website:

www.emeraldgrouppublishing.com/licensing/reprints.htm

Or contact us for further details: permissions@emeraldinsight.com 